\title{
Histological and scanning electron microscopic study of the effect of UV-A radiation on the land snail Monacha obstructa
}

\author{
SM Ali ${ }^{*}$ iD and SM Said
}

\begin{abstract}
Background: Monacha obstructa is one of the most abundant gastropod of Egyptian farms. It is a destructive land snail as they cause great damage to vegetables and crops. The present study aimed to control snails by ultraviolet radiation.

Materials and methods: Snails under study were subjected to the same dose of UV-A radiation for two different periods. The source of radiation was UV-fluorescent lamps, UV-A $366 \mathrm{~nm}$. Small pieces of mantle edge, foot, digestive gland, and intestine of treated and untreated snails were taken and prepared for histological examination by light microscope. While small pieces of mantle edge and foot only were prepared for scanning electron microscopic examination.

Results: Histopathological changes in the mantle, foot, digestive gland, and intestine of treated snails were studied. The changes included destruction and disorganization of many cell types. UV-A radiation affected the fitness of the snails; they became less active. The changes in different organs will lead to alteration in their functions.
\end{abstract}

Conclusions: UV-A has a destructive effect on different organs of the snails under study. This effect will lead to the control of this snail (Monacha obstructa).

Keywords: Monacha obstructa, Land snails, Mantle, Foot, Digestive gland, Intestine, Ultraviolet radiation, Histological alteration, Scanning electron microscope

\section{Background}

Solar radiation consists of three-wavelength bands $400-$ $320 \mathrm{~nm}$ (UV-A), 320-290 nm (UV-B), and 290-190 nm $(\mathrm{UV}-\mathrm{C})$. All the previous wavelengths are invisible to the human eye. UV-A radiation is not completely absorbed by ozone. It is scattered by light so it is attenuated before reaching the earth surface (Steeger et al. 2001). The effect of ultraviolet radiation (UV) is important to various aquatic and terrestrial organisms. The abnormal effects of UV radiation exhibit various important biochemical and physiological processes (Martin, 1999). UV radiation has direct and indirect effect on organisms. The direct effect is the alteration, which occurs in the

\footnotetext{
* Correspondence: safaa.mohamed1@science.au.edu.eg

Zoology Department, Faculty of Science, Assiut University, Assiut, Egypt
}

organic contents of cells, while the indirect effect includes the change in the environment that surrounds the organism (Ruelas et al. 2006). The direct and indirect effects include lethality, carcinogenesis, and mutagenesis (Weber, 2005).

Mohammad (2016) reported that UV-A radiation induced biochemical, histological, and morphological alteration of Simocephaus vetulus (zooplankton). These changes depended on the period of exposure to radiation.

Nabih and Abd El Hamid (1984) reported that UV radiation has a lethal effect on Biomphalaria alexandrina, and this effect depended on the exposure time. McNamara and Hill (1999) studied the effect of UV-B radiation on the snail Elimia clavaeformis and Physella 


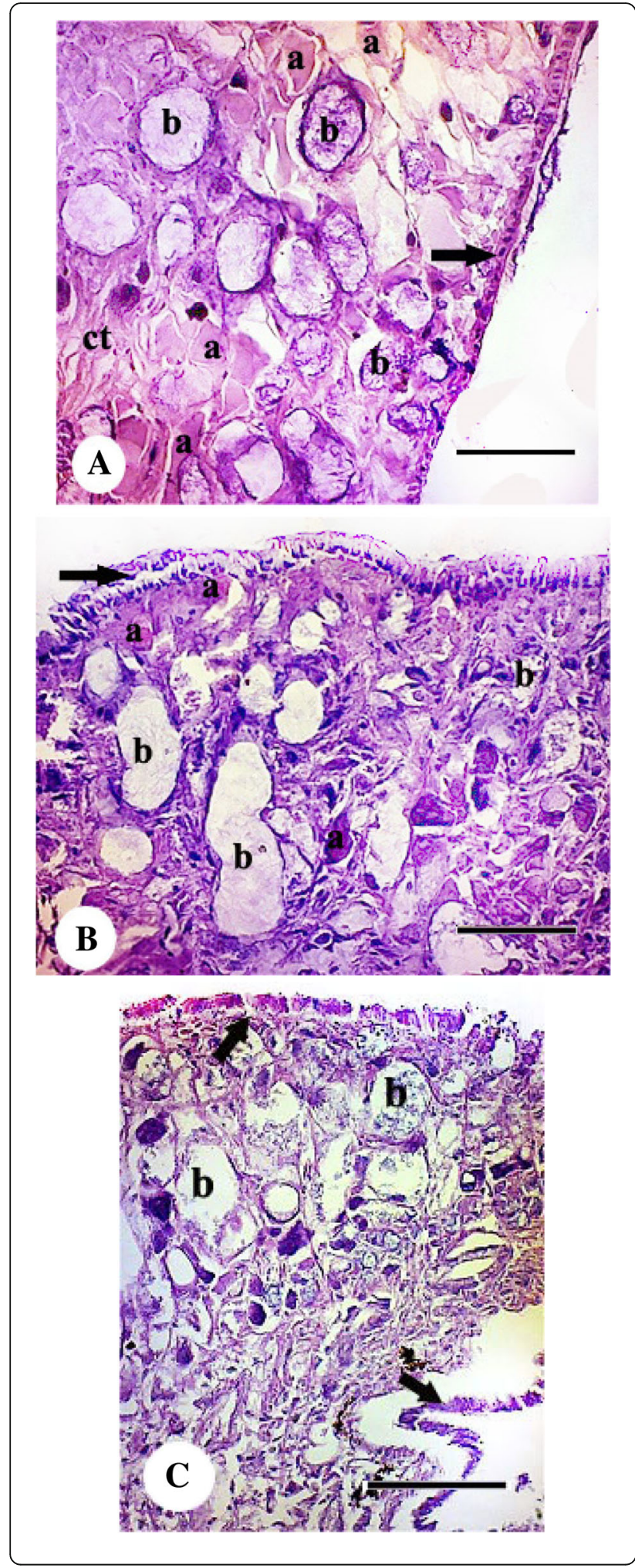

Fig. 1 A Photomicrograph of the mantle edge of unexposed snails showing single epithelial layer (arrow), unicellular glands with acidophilic secretory materials (a), unicellular glands with basophilic secretory materials (b), and connective tissue (ct). B Photomicrograph of the mantle edge of snails exposed to UV-A radiation for $3 \mathrm{~h}$ for two successive days showing separation of the epithelial layer (arrow), unicellular glands with acidophilic secretory material (a), and the unicellular glands that have basophilic secretory material increased in size and number (b). C Photomicrograph of snails exposed to UV-A radiation for $3 \mathrm{~h}$ for three successive days showing ruptured epithelial layer with disintegrated cells (arrows) and glands with basophilic secretory materials (b)

gyrina, and reported that the survival rate of the exposed snails depended on the duration of exposure and the size of snails. Mohammad and Ali (2012) studied the effect of UV-A radiation on the blood cells (hemocytes) of the land snail Eobania vermiculata and recorded many cellular alterations to the different hemocytes.

The land snail Monacha obstructa is one of the most important gastropod of Egyptian farms as it causes major threat to agriculture in Assiut, Egypt (Ali et al. 2015). The present study aims to study the use of UV-A radiation to control the destructive snail Monacha obstructa.

\section{Materials and methods}

Collection of samples: adult snails (Monacha obstructa) were collected from Assiut University farm. Then, snails were transferred in plastic bags to the laboratory. Snails were fed on lettuce and kept for 1 week for acclimatization. Snails were classified into three groups (each group consists of 15 snails): untreated group and two UV-A treated groups. The treated snails were exposed to UV-A radiation from UV-A source for two different intervals (the first group was exposed to the radiation for $3 \mathrm{~h} /$ day for two successive days, while the second group was exposed to the radiation for $3 \mathrm{~h} /$ day for three successive days).

UV-A source: snails were exposed to UV-A using UV-A source fitted $15 \mathrm{~cm}$ above the snails. (ULTRAVIOLET Products, Inc., San Gabriel, CA, USA, model UVL_56).

\section{Microscopic study}

Small pieces of mantle edge, foot, digestive gland, and intestine of treated and untreated snails were taken and prepared for histological examination. Paraffin sections were stained with Hemotoxylin and Eosin stain.

Small pieces of mantle edge and foot were stuck onto holders then coated with $100 \AA$ gold and then examined with stereo scanning electron microscope and photographed at the Electron Microscope Unit at Assiut University. 




Fig. 2 A, B Scanning electron micrograph of the outer surface of mantle of unexposed snails showing $\mathbf{A}$ cracks (c) and small pores (sp), B folds (f), and large pores (Ip). C, D Scanning electron microgrph of outer surface of the mantle of snails exposed to UV-A radiation for $3 \mathrm{~h}$ for two successive days showing C crack (c) and pore (p). D Deep folds (arrows). E Scanning electron micrograph of outer surface of the mantle of snails exposed to UV-A radiation for $3 \mathrm{~h}$ for three successive days shows pore ( $p)$, crack (c), and shallow folds ( $f$ )

\section{Results}

After treatment of snails with UV-A radiation, the snails became less active, but no mortality was recorded. Many histological changes were recorded in mantle edge, foot, digestive gland, and intestine.

\section{Mantle edge}

Examination of the transverse sections of the mantle edge of unexposed snails under light microscope shows that the outer layer of mantle is covered with a single layer of simple cuboidal epithelial tissue, while the inner layer is composed of a connective tissue that provided with two types of unicellular glands. The first type of glands is greater in number and contains basophilic secretory material; the second type is fewer in number and contains acidophilic secretory material (Fig. 1A).

In snails exposed to UV-A radiation for $3 \mathrm{~h}$ for two successive days, the epithelial cells that cover the mantle were separated from the inner layer. The glands that contain basophilic secretory material increased in size and number (Fig. 1B).

In snails exposed to UV-A radiation for $3 \mathrm{~h}$ for three successive days, the epithelial layer is ruptured and its cells disintegrated (arrows); some of the unicellular glands with basophilic secretory material became empty while the glands with acidophilic secretory material could not be distinguished (Fig. 1C).

Examination of the mantle edge of unexposed snails with scanning electron microscope showed that the outer surface of the mantle is rough, folded with cracks, with many small and few large pores (Fig. 2A, B).

In snails exposed to UV-A radiation for $3 \mathrm{~h}$ for two successive days, the cracks in the outer surface of the mantle edge became wider, most pores became bigger, and the folds became deeper (Fig. 2).

In snails exposed to UV radiation for $3 \mathrm{~h}$ for three successive days, the folds of the outer surface of the mantle edge became shallow while pores and cracks became very small (Fig. 2E).

\section{Foot}

The foot of Monacha obstructa is composed of an outer single layer of epithelial tissue that covers an inner layer of connective tissue. The sole of the foot is covered with 
a simple columnar epithelium while its sides are covered with simple cuboidal epithelium. The connective tissue layer beneath the epithelial layer contains many glands. Glands at the sole region are greater in number than that at the side region and are deeply embedded in the connective tissue while those of the side region are superficial glands (Fig. 3A-C).

The exposure to UV-A for $3 \mathrm{~h}$ for two successive days leads to rupture of the epithelial layer of the foot sole, and the folds became more deep with undifferentiated epithelial cells (Fig. 3D), also the folds of the sides of the food became deeper and the epithelial layer that covers the sides became ruptured, and the connective tissue layer disorganized and many spaces appeared within it. Hemocyte infiltration also was reported in the connective tissue layer of the foot sides (Fig. 3E).

After exposure to the radiation for $3 \mathrm{~h}$ for 3 days, both the connective and the epithelial tissue layers became ruptured. The boundaries among the epithelial cells could not be distinguished (Fig. 3F). While in the sides of the foot, the epithelial layer separated in many places from the underlying connective tissue layer. Most of the glands disintegrated (Fig. 3G).

Examination of the foot of unexposed snails by scanning electron microscope showed that the surface of the sole has narrow grooves while the grooves of the sides

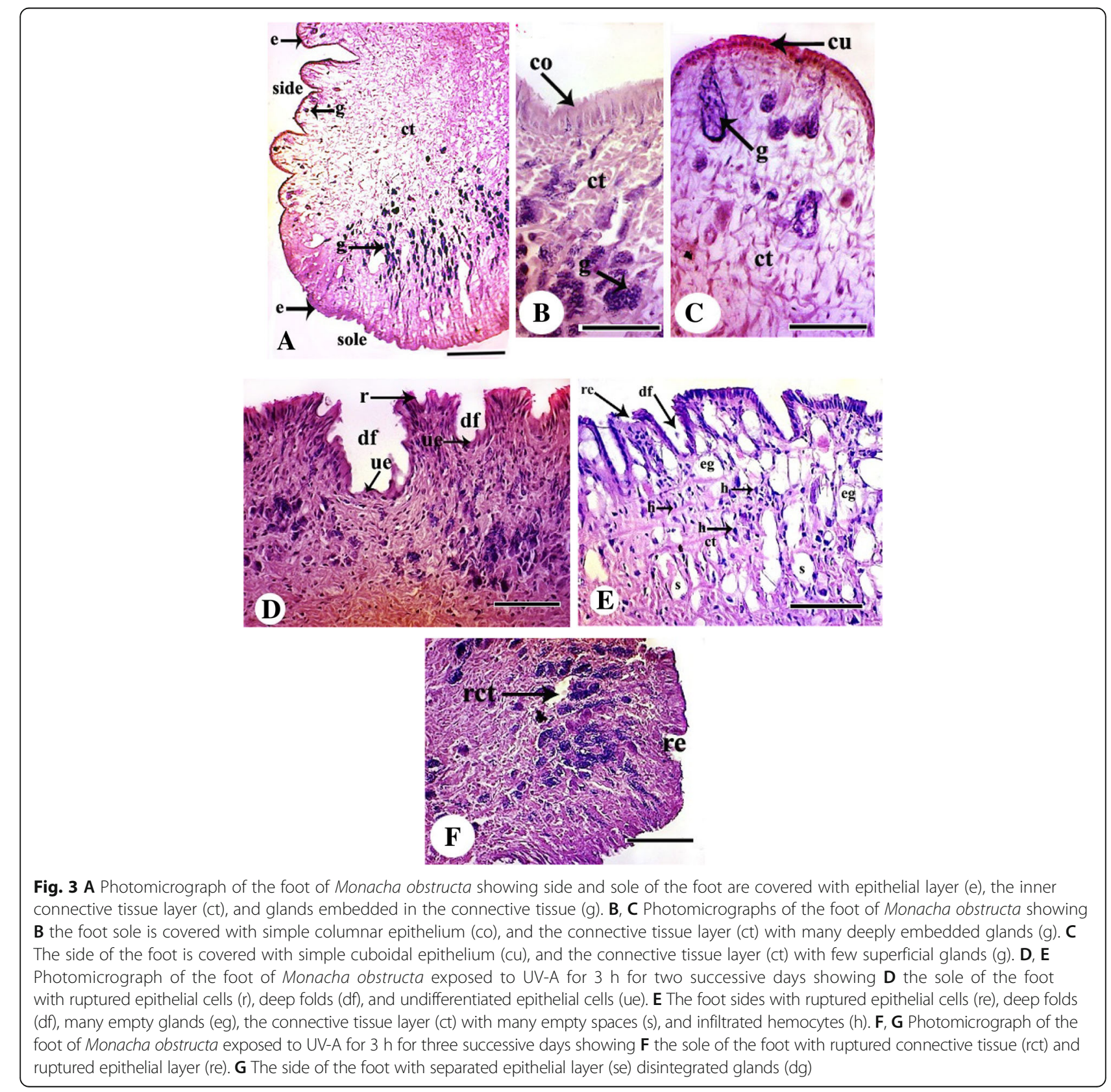


are wider (Fig. 4A). After exposure to UV-A for $3 \mathrm{~h}$ for 2 days, the grooves on the foot surface became wider and many pores appeared (Fig. 4B).

\section{Digestive gland}

The digestive gland of unexposed snails consists of many tubules; each of them lined with three types of epithelial cells; digestive cells (elongated cells with many small granules), calcium cells (triangular in shape with large basic nucleus), excretory cells (elongated cells with large vacuole) and thin cells (very thin and long cells). Digestive tubules are separated by intertubular connective tissue and surrounded by a thin layer of circular muscle fibers (Fig. 5A).

After exposure to UV-A for $3 \mathrm{~h}$ for two successive days, the lumen of the digestive tubules became wider and the only cell type, which could be distinguished, was the calcium cell with its large basal nucleus. However, the other epithelial cells lost their normal shape, and most of them became cuboidal in shape (Fig. 5B). In



Fig. 4 A, B Scanning electron microscope of the foot of Monacha obstructa showing $\mathbf{A}$ unexposed snails; the foot sole (left) with many narrow grooves (ng), and the sides (right) with many wide grooves (wg). B Snails exposed to UV-A for $3 \mathrm{~h}$ for 2 days; the grooves became wider (g), and many pores appeared ( $p$ )

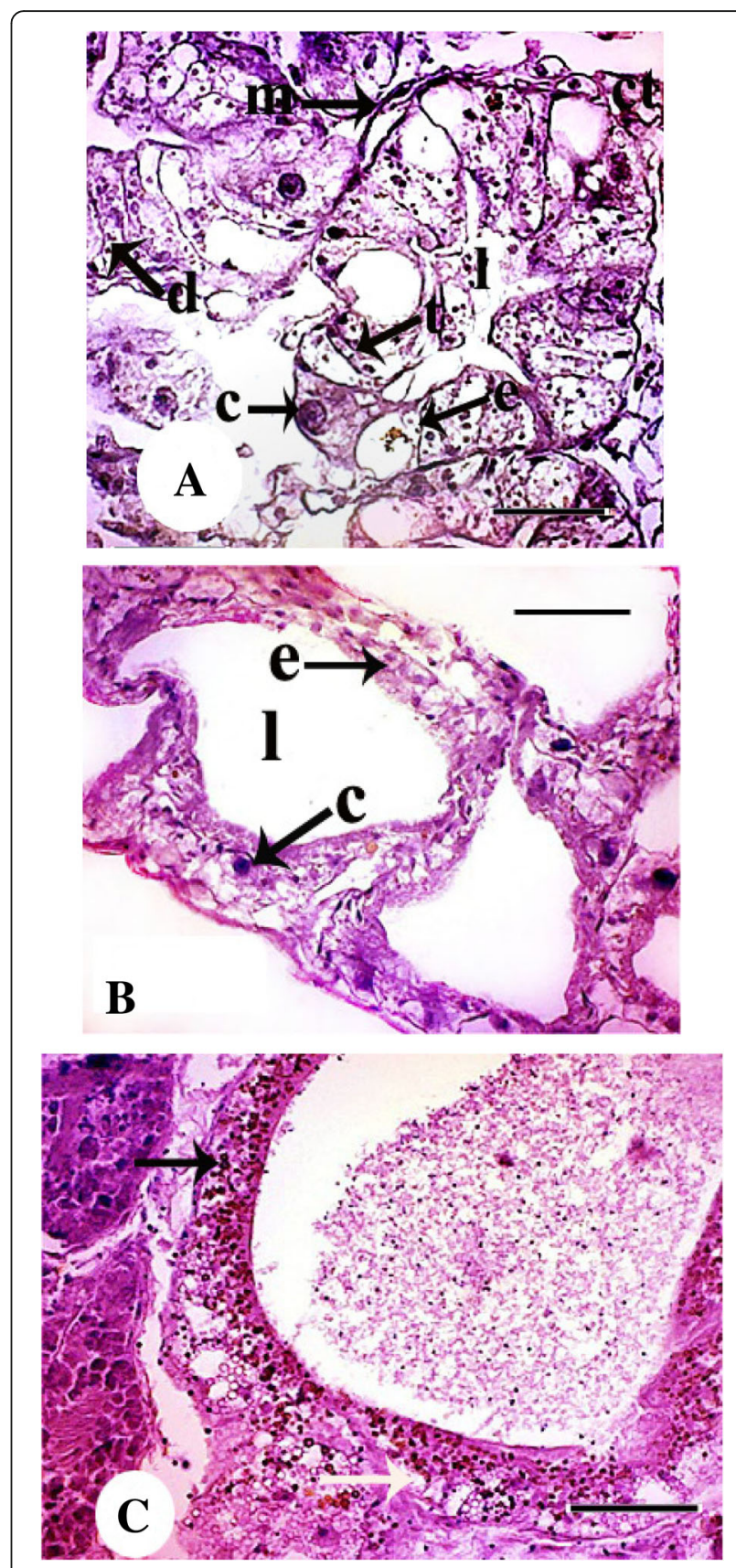

Fig. 5 A Photomicrograph of digestive gland of unexposed snails showing the digestive tubules surrounded by circular muscle fibers $(\mathrm{m})$, separated from each other by connective tissue (ct); each tubule have a central lumen (l) which is surrounded with calcium cells (c), excretory cells (e), digestive cells (d), and thin cells (t). B Photomicrograph of digestive gland of snails exposed to UV-A radiation for $3 \mathrm{~h}$ for two successive days shows cuboidal epithelial cell (e), calcium cell (c), and lumen (I). C Photomicrograph of digestive gland of snails exposed to UV-A radiation for $3 \mathrm{~h}$ for three successive days showing digestive tubules with many vacuoles (white arrow) and darkly stained granules (black arrow) 
snails exposed to $3 \mathrm{~h}$ for 3 days, the lumen of the digestive tubules became very wide, and the epithelial cells that lined the digestive tubules of the digestive gland were completely disintegrated, and many vacuoles and darkly stained granules were detected (Fig. 5C).

\section{Intestine}

The intestine of unexposed snails is lined with simple columnar epithelium that covered with a brush border. The outer layer of the intestine is composed of a connective tissue layer. Snails exposed to UV-A for $3 \mathrm{~h}$ for 2 days showed great destruction in both the epithelial and connective tissue layers, and nuclei of the epithelial tissue layer appeared randomly distributed (Fig. 6A). While in snails exposed to UV-A for $3 \mathrm{~h}$ for 3 days, both

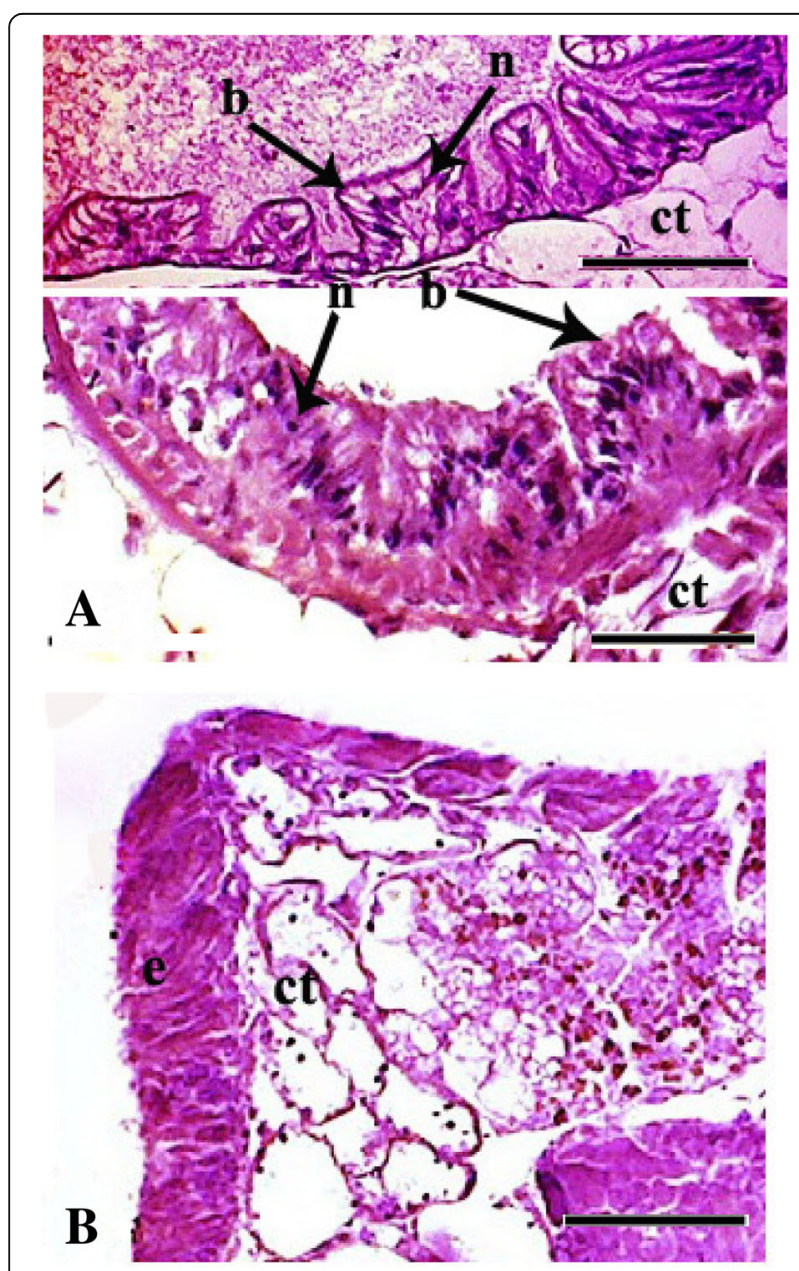

Fig. 6 A, B Photomicrograph of the intestine of Monacha obstructa showing $\mathbf{A}$ presence of a brush border covering the epithelial lining (above) (b), and nuclei are regularly arranged (n). After exposure to UV-A for $3 \mathrm{~h}$ for 2 days (below) showing irregular arrangement of nuclei (n) and absence of the brush border (b). B Snails exposed to UV-A for $3 \mathrm{~h}$ for three successive days suffered from destruction of both the epithelial tissue (e) and the connective tissue (ct) epithelial and connective tissue layers were greatly destroyed (Fig. 6B).

\section{Discussion}

The natural sunlight which contains both UV-A and UV-B radiation does not affect the survival rate and hatching of eggs of Lymnaea as reported by Wahl (2008). While he reported that Planorbarius embryos showed $100 \%$ mortality if they were exposed to natural sun light (which contains both UV-A and UV-B) or UV-A only. The present study recorded many histological and behavioral (snails became inactive and stayed in the bottom of the container to avoid UV-A radiation) responses of Monacha obstructa to the different treatment with UV-A radiation, but there is no mortality recorded until the end of the experiment.

Variable negative responses of some invertebrate species to artificial UV radiation were recorded (Cywinskal et al. 2000). Under constant exposure to UV and photosynthetically active radiation (PAR), the acute lethal and sublethal response was recorded. In the present study, the only behavioral sublethal response was the slow motion and inactivity of snails which may be due to partial paralysis as recorded by Cywinskal et al. (2000). They also recorded a slow movement, but they recorded changes in pigmentation (the later response had not been recorded in the present study). Cywinskal et al. (2000) also studied a series of UV-B, UV-A, and PAR treatments, applied separately and in combination and revealed a positive role for both UV-A and PAR in slowing down UV-B damage.

UV radiation decreases the density of invertebrates in clear water lakes suggesting a direct relation between invertebrate abundance and exposure to ultraviolet radiation. Cooke et al. (2008) studied the effect of UV on freshwater crustacean; he detected that the UV influenced the vertical migration of these invertebrates.

Chuang et al. (2006) studied the behavioral and histological changes in earthworms due to the exposure to UV. The study revealed that exposure to UV caused death of some individuals. Exposure to UV resulted in acute and chronic effect. The acute effect was abnormal muscle contraction which leads to S-shaped movements and jumping of the animals. This behavior may be due to the damage in the coordination between the longitudinal and circular muscles. While the chronic effect included histological alteration in the muscle and skin. UV-A radiations showed no effect on earthworms skin. While animals exposed to UV-B radiation suffered from thickening and breaking down of the cuticle layer and necrosis of the epidermis and circular muscles.

Terrestrial animals can tolerate UV than aquatic animals because they can protect themselves by pigmentation and 
integument derivatives such as shell, hair, feathers, or scales (Gies et al. 1995; Hill et al. 1997).

In the present study, the exposed tissues such as the mantle edge and foot, which were exposed to UV-A radiation, suffered from alteration in the histological structure. The epithelial tissue that covers the mantle edge separated from the underlying tissue. Alteration in the connective tissue layer and its glands also was recorded. Examination of both mantle edge and foot by scanning electron microscope demonstrated that cracks and pores in the outer surface of the mantle edge became wider and folds became deeper.

By exposing snails to UV-A radiation for a longer time, the folds of the outer surface of the mantle edge became shallow, and pores and cracks became smaller. The epithelial and connective tissues of the foot were ruptured after exposure to UV-A radiation. Also, the grooves on the foot surface became wider, and the number of pores increased.

Exposure of Biomphalaria glabrata to UV-B inhibits feeding of snails, induces abnormal growths on the region of the head and foot, and leads to the appearance of forked tentacle (Ruelas et al. 2006). The branch of the forked tentacle had the same histological structure of the original tentacle except in covering epithelial layer which was thinner. They explained the significant mortality rate observed due to the damage occurred by UV-B radiation exposures which lead to damage of head, foot, surface epithelial tissue, muscular tissue, hemolymph, glands, and nervous tissue, and also the alteration which occurred in the digestive tract.

In the present study, many alterations in the histology of the digestive gland and the intestine were recorded. The different epithelial cells that lined the digestive tubules in the digestive glands became cuboidal (shorter), and most of the different types of the lining epithelium could not be distinguished. Extensive exposure to UV-A leads to destruction of the epithelial cells of the digestive tubules. The epithelial lining and the connective tissue layer of the intestine were greatly destroyed due to exposure to UV-A. The destruction and abnormalities of the different tissues of the snails will lead to slowing or stopping of their biological activities which finally leads to snails' control.

\section{Conclusion}

UV-A has a destructive effect on the harmful land snail Monacha obstructa so we can use UV-A to control this land snail.

\section{Abbreviations}

UV-A: Solar radiation of wavelength bands 400-320 nm; UV-B: Solar radiation of wavelength bands 320-290 nm; UV-C: Solar radiation of wavelength bands 290-190 $\mathrm{nm}$

\section{Acknowledgements}

The authors would like to express their thanks to Prof. Dr. Ahmed Hamed, Prof. Dr. Naser El Shimy and Dr. Torkia Abul-Maged for their continuous help and advice.

\section{Funding}

Not applicable.

\section{Availability of data and materials}

Please contact author for data requests.

\section{Authors' contributions}

Both authors designed, performed the practical part of the work, read, and approved the final manuscript.

\section{Ethics approval}

The authors declare that this work was carried out within an appropriate ethical framework.

\section{Consent for publication}

Not applicable.

\section{Competing interests}

The authors declare that they have no competing interests.

\section{Publisher's Note}

Springer Nature remains neutral with regard to jurisdictional claims in published maps and institutional affiliations.

Received: 17 August 2018 Accepted: 4 January 2019

Published online: 06 February 2019

\section{References}

Ali, S. M., Mohammed, T. A., Mandour, A. M., \& Abd EL-Malek, A. R. (2015). Effect of Acacia nilotica and Cuminum cyminum extracts on Eobania vermiculata and Monacha obstructa (land snails). Egypt. J. Zool., 64, 117-130.

Chuang, S.-C., Lai, W.-S., \& Chen, J.-H. (2006). Influence of ultraviolet radiation on selected physiological responses of earthworms. The J. Experimental Biology, 209, 4304-4312.

Cooke, S. L., Williamson, C. E., Leech, D. M., Boeing, W. J., \& Torres, L. (2008). Effects of temperature and ultraviolet radiation on diel vertical migration of freshwater crustacean zooplankton. Canadian J. Fisheries and Aquatic Sciences, 65(6), 1144-1152.

Cywinskal, A., Crump, D., \& Lean, D. (2000). Influence of UV radiation on four freshwater invertebrates. Photochemistry and Photobiology, 72(5), 652-659.

Gies, H. P., Roy, C. R., Toomey, S., MacLennan, R., \& Watson, M. (1995). Solar UV exposures of three groups of outdoor workers on the sunshine coast, Queensland. Photochem. Photobiol., 62, 1015-1021.

Hill, W. R., Dimick, S. M., McNamara, A. E., \& Branson, C. A. (1997). No effects of ambient UV radiation detected in periphyton and grazers. Limnol. Oceonogr., 42(4), 769-774.

Martin, L. R. (1999). Survey of the potential effects of increasing UV-B radiation on the biosphere. AOI Government, Report Announcement and India (GRA \& I). Issue is NTIS/ADA.361 (p. 283).

McNamara, A. E., \& Hill, W. R. (1999). Effects of UV-B dose and irradiance: comparison among grazers. J N Amer Benth Soc., 18, 370-380 in: Ruelas et al., 2006.

Mohammad, W. A. (2016). Impact of some Ecological factors on zooplankton communities at Assiut, Egypt. Egypt: A Ph.D. thesis Fac. Sci., Assiut University.

Mohammad, T. A., \& Ali, S. M. (2012). Effect of UV-A radiation on Eobania vermiculata (A common land snail in Egypt) 1- Haemolymph. J. Egypt. Ger. Soc. Zool. Vol. (64D): Invertebrate Zoology \& Parasitology, 125-141.

Nabih, I., \& Abd El Hamid, A. Z. (1984). Biochemical studies on the genetic material of fresh water snails, intermediate hosts of schistosomiasis. 1984-I. Effect of ultraviolet radiation as physical mutagen on the chemical nature of deoxyribonucleic acid. Cell Molec. Biol., 30, 33-36 in Ruelas et al., 2006.

Ruelas, D. S., Karentz, D., \& Sullivan, J. T. (2006). Lethal and sub-lethal effects of UV-B on juvenile Biomphalaria glabrat (Mollusca: Pulmonata). Journal of Invertebrate Pathology, 93(3), 192-200.

Steeger, H. U., Freitag, J. F., Michl, S., Wiemer, M., \& Paul, R. J. (2001). Effects of UV$B$ radiation on embryonic, larval and juvenile stages of northern sea plaice 
(Pleuronectes platessa) under simulated ozone-hole conditions. Helgoland Marine Research, 55, 56-66.

Wahl, M. (2008). Ecological modulation of environmental stress: Interactions between ultraviolet radiation, epibiotic snail embryos, plants and herbivores. J. Animal Ecology, 77, 549-557.

Weber, S. (2005). Light-driven enzymatic catalysis of DNA repair: A review of

recent biophysical studies on photolyase. Biochimica et Biophysica Acta, 1707, $1-23$.

Submit your manuscript to a SpringerOpen ${ }^{\mathcal{O}}$ journal and benefit from:

- Convenient online submission

- Rigorous peer review

- Open access: articles freely available online

- High visibility within the field

- Retaining the copyright to your article

Submit your next manuscript at $\boldsymbol{\sim}$ springeropen.com 